\title{
Downward particle flux and carbon export in the Beaufort Sea, Arctic Ocean; the role of zooplankton
}

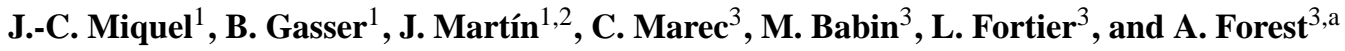 \\ ${ }^{1}$ International Atomic Energy Agency, Environment Laboratories, 4, quai Antoine 1er, 98000, Monaco \\ ${ }^{2}$ Centro Austral de Investigaciones Científicas (CADIC-CONICET), Houssay 200, 9410 Ushuaia, Argentina \\ ${ }^{3}$ Takuvik Joint International Laboratory, Université Laval (Canada) - CNRS (France), Département de Biologie and \\ Québec-Océan, Université Laval, G1V 0A6, Canada \\ apresent address: Golder Associates Ltd. 200-1170 boulevard Lebourgneuf, Québec, G2K 2E3, Canada
}

Correspondence to: J.-C. Miquel (j.c.miquel@iaea.org)

Received: 30 November 2014 - Published in Biogeosciences Discuss.: 19 January 2015

Revised: 29 July 2015 - Accepted: 10 August 2015 - Published: 28 August 2015

\begin{abstract}
As part of the international, multidisciplinary project Malina, downward particle fluxes were investigated by means of a drifting multi-sediment trap mooring deployed at three sites in the Canadian Beaufort Sea in late summer 2009. Mooring deployments lasted between 28 and $50 \mathrm{~h}$ and targeted the shelf-break and the slope along the BeaufortMackenzie continental margin, as well as the edge between the Mackenzie Shelf and the Amundsen Gulf. Besides analyses of $\mathrm{C}$ and $\mathrm{N}$, the collected material was investigated for pigments, phyto- and microzooplankton, faecal pellets and swimmers.

The measured fluxes were relatively low, in the range of $11-54 \mathrm{mg} \mathrm{m}^{-2} \mathrm{~d}^{-1}$ for the total mass, $1-15 \mathrm{mg} \mathrm{C} \mathrm{m}^{-2} \mathrm{~d}^{-1}$ for organic carbon and $0.2-2.5 \mathrm{mg} \mathrm{N} \mathrm{m}^{-2} \mathrm{~d}^{-1}$ for nitrogen. Comparison with a long-term trap data set from the same sampling area showed that the short-term measurements were at the lower end of the high variability characterizing a rather high flux regime during the study period.

The sinking material consisted of aggregates and particles that were characterized by the presence of hetero- and autotrophic microzooplankters and diatoms and by the corresponding pigment signatures. Faecal pellets contribution to sinking carbon flux was important, especially at depths below $100 \mathrm{~m}$, where they represented up to $25 \%$ of the total carbon flux. The vertical distribution of different morphotypes of pellets showed a marked pattern with cylindrical faeces (produced by calanoid copepods) present mainly within the euphotic zone, whereas elliptical pellets (produced mainly by smaller copepods) were more abundant at mesopelagic
\end{abstract}

depths. These features, together with the density of matter within the pellets, highlighted the role of the zooplankton community in the transformation of carbon issued from the primary production and the transition of that carbon from the productive surface zone to the Arctic Ocean's interior. Our data indicate that sinking carbon flux in this late summer period is primarily the result of a heterotrophic-driven ecosystem.

\section{Introduction}

The export of carbon from the surface to the deep ocean via the sinking of particulate organic matter is a major process of the ocean carbon cycle and a key factor in the regulation of the atmospheric $\mathrm{CO}_{2}$ level (Archer et al., 2000; Siegenthaler et al., 2005). The increase of the latter and the related global warming have become a common subject in climate change research, in which the Arctic Ocean is a privileged target, since it is one of the most vulnerable regions to climate change (Walsh, 2008). Vertical flux of particulate organic carbon (POC) in the Arctic Ocean shows multiple facets. There is a marked regional variability illustrated by generally low POC fluxes $\left(<100 \mathrm{mg} \mathrm{m}^{-2} \mathrm{~d}^{-1}\right)$ in the central Arctic Ocean (Lalande et al., 2014; Olli et al., 2007) and high fluxes $\left(>100 \mathrm{mg} \mathrm{m}^{-2} \mathrm{~d}^{-1}\right)$ over the continental shelves and in polynyas (Amiel et al., 2002; Lalande et al., 2009). Several factors lead to these different flux scenarios. Over the shelves, the interplay between seasonal ice 
coverage and break-up, episodical events of wind-driven upwelling and resuspension of sediment seems to be the driving force for highly productive regimes and subsequent elevated POC fluxes (Forest et al., 2013; Lalande et al., 2014; Reigstad et al., 2011; Tremblay et al., 2014; Wassmann et al., 2006). Fluxes in the Central Basin are low due to an ineffective "biological pump" (Honjo et al., 2010), as well as to a low primary productivity related to a lack of nutrient supply into the euphotic zone (Lalande et al., 2014).

Annual and seasonal variations are in a first place related to the particular light regime over the Arctic Ocean (Wassmann et al., 2004), the annual light cycle being very regular in contrast to the ice coverage, which is not only irregular with respect to the seasonal break-up in summer but, in the light of global warming, is deemed to disappear at least in parts of this ocean (Leu et al., 2011; Wassmann, 2011). In the Beaufort Sea, several studies with intercepting sediment traps have shown that the ice-free season is normally the period where maximum fluxes were observed, but they were highly variable within this season between different years (Forest et al., 2007, 2010; Juul-Pedersen et al., 2010). However, high temporal variability was also observed with regard to shelf-basin exchanges, where lateral inputs from nepheloid layers or eddy-driven processes led to flux pulses over the shelf break (Forest et al., 2007) and even beyond the shelf out in the basin (O'Brien et al., 2011). POC flux variability does not only depend on physical but also on biological and chemical parameters, of which the latter have an indirect influence on POC flux through nutrient-limited primary production (see above). The main actors of the biotic control of sinking organic particles are on the one hand bacteria, which reduce the flux by decomposition of the particles (Kellogg et al., 2011), and on the other hand grazing zooplankton, primarily copepods in arctic waters, which modulate the flux by the ingestion of phytoplankton and the production of faecal pellets (Wiedmann et al., 2014).

In fact, the different natures of variability in the vertical particle flux are reflected in one of the objectives of the Malina project: to understand the control of biogeochemical fluxes through light penetration and the impact of ongoing climate change on these fluxes. Malina aims at building a self-consistent data set in order to improve our present understanding of biogeochemical fluxes in this remote ocean and the prediction of future changes through modelling. Concerning the vertical particle flux, Forest et al. (2013) estimated POC fluxes over the entire Mackenzie shelf and adjacent areas and explored the spatial variability of these fluxes and its forcing factors. In the present study, our goal is to present a snapshot of the POC fluxes measured in situ along the shelf-break in a more comprehensive manner using a set of parameters obtained from the particulate material. We aim to document the composition of sinking particles throughout the water column to highlight some processes that shape the transit of these particles from the surface to the deep ocean.

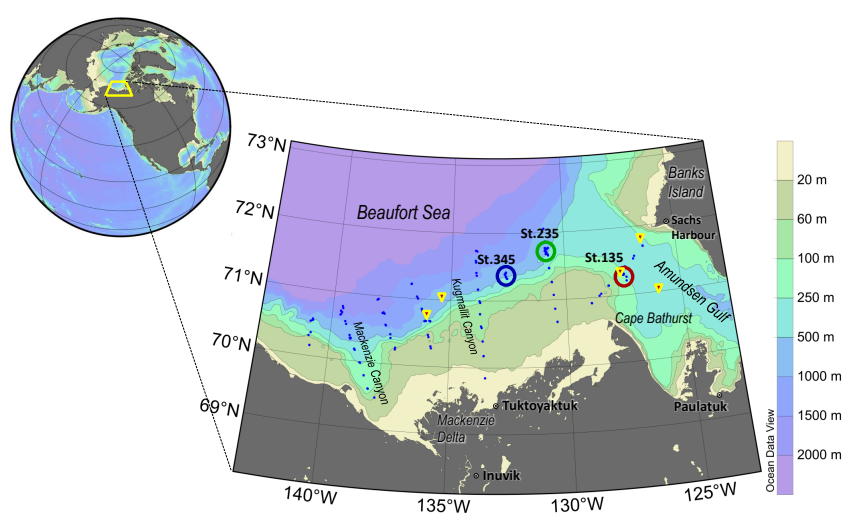

Figure 1. Map of the region and close-up on sampling area; blue, green and red circles represent areas of drifting trap deployment and yellow triangles sites of long-term moorings. Blue dots depict main CTD stations of the Malina programme sampling grid. Drifting trap sampling was limited to the eastern part of the area because of the sea-ice cover during the first part of the cruise.

\section{Material and methods}

\subsection{Drifting line deployment and water column survey}

Drifting sediment trap moorings were deployed at three sites of the Beaufort Sea during leg $2 \mathrm{~b}$ of the Malina field campaign in August 2009. The location of the deployment sites is represented in Fig. 1. It shows the sampling grid of the Malina programme and the trap mooring sites within the transects crossing the Mackenzie shelf. Site 345 had to be moved to the east due to ice coverage at the desired location of the corresponding transect. All three sites are situated on the slope of the Mackenzie shelf in the south-eastern part of the Beaufort Sea, site 135 being the easternmost at the entrance of the Amundsen Gulf. Throughout this article, the three sampling sites will be presented in the order from west to east, i.e. site 345 as the westernmost, site 235 further east and site 135 as the easternmost one.

Figure 2 shows the schematic drawing of the moorings. Each mooring line was equipped with four traps at nominal depths of $40,85,150$ and $210 \mathrm{~m}$. Based on the data from the hydrographical casts the trap depths were chosen to monitor (1) the fluxes out of the polar mixed layer (PML) likely to be influenced the most by the inputs from the Mackenzie River, (2) the fluxes out of the layer with highest phytoplankton biomass and production, (3) the fluxes out of the euphotic zone and (4) the fluxes monitored at a depth of other long-term moorings in the area and therefore best comparable with these data. For each deployment, the length of the mooring line and sampling intervals were adapted to the constraints imposed by bottom depth, ice cover and survey schedules. For instance at site 135 , the trap at $210 \mathrm{~m}$ had to be removed from the mooring to avoid its grounding. Detailed information for each trap and mooring deployment is 
Table 1. Drifting line deployment specifications.

\begin{tabular}{llll}
\hline Sampling stations & 345 & 235 & 135 \\
\hline Deployment depths (m) & $38,85,152,211$ & $38,83,151,210$ & $39,87,154$ \\
Bottom depth (m) & $500-600$ & $550-650$ & $220-230$ \\
Deployment date (UTC) & 14 Aug 2009 & 22 Aug 2009 & 20 Aug 2009 \\
Retrieval date (UTC) & 16 Aug 2009 & 24 Aug 2009 & 22 Aug 2009 \\
Deployment location & $71.330^{\circ} \mathrm{N}$ & $71.775^{\circ} \mathrm{N}$ & $71.321^{\circ} \mathrm{N}$ \\
& $132.556^{\circ} \mathrm{W}$ & $130.726^{\circ} \mathrm{W}$ & $127.495^{\circ} \mathrm{W}$ \\
Retrieval location & $71.390^{\circ} \mathrm{N}$ & $71.713^{\circ} \mathrm{N}$ & $71.213^{\circ} \mathrm{N}$ \\
& $132.649^{\circ} \mathrm{W}$ & $130.797^{\circ} \mathrm{W}$ & $127.344^{\circ} \mathrm{W}$ \\
Sampling duration (h) & 32 & 50 & 28 \\
\hline
\end{tabular}

* Indicates depth range within drifting track

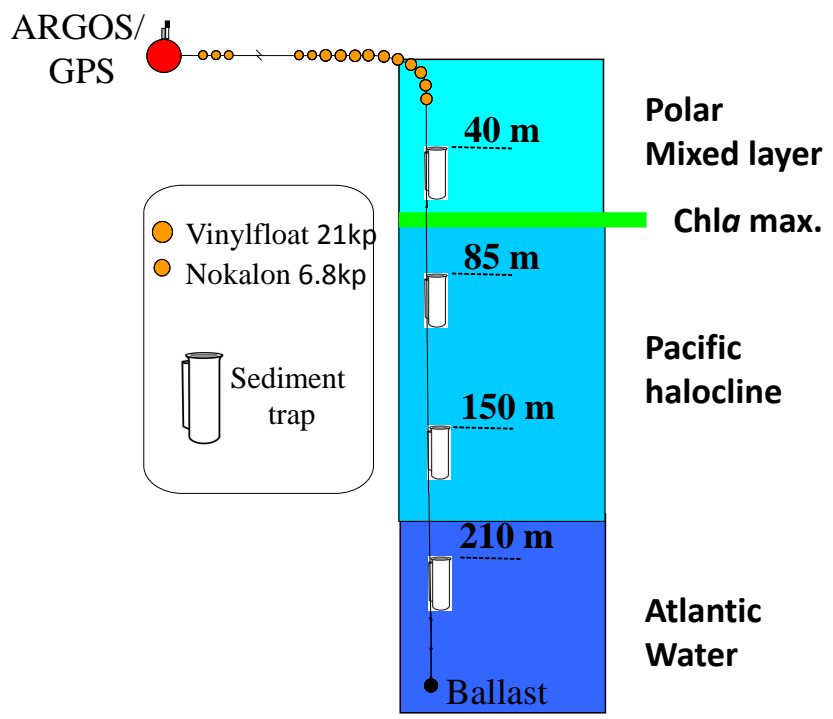

Figure 2. Mooring configuration showing the depth of each sediment trap with respect to its position within the different water masses and to the horizon of maximum chlorophyll $a$.

given in Table 1. The traps used were TECHNICAP PPS3/3 of cylindro-conical body shape with an aspect ratio of 2.5 in the cylindrical part and 4.0 over the whole length. The unbaffled aperture of the traps had a collection surface of $0.125 \mathrm{~m}^{2}$. Particles were collected in $260 \mathrm{~mL}$ polyethylene bottles poisoned with a solution of borax buffered formaldehyde $5 \%$ $\left(\mathrm{v} \mathrm{v}^{-1}\right)$ in filtered $(0.2 \mu \mathrm{m})$ seawater. The $\mathrm{pH}$ was checked with a pH-metre after the deployment and immediately before processing the samples in the laboratory. All samples showed a value between 8.3 and 8.5 .

At all three sites, multiple deployments of a rosette profiler equipped with a conductivity-temperature-depth system (CTD, Seabird SBE-911+), a fluorometer (Seapoint), a transmissometer (Wetlabs C-Star), and a particle camera (Underwater Vision Profiler 5, UVP5, Picheral et al., 2010), were conducted in order to document the water column properties before, during and after the drift of the mooring equipped with sediment traps.

\subsection{Processing and analysis of samples}

Upon recovery on board, the sample cups were stored at $4{ }^{\circ} \mathrm{C}$ in the dark until they were processed.

Swimmers were handpicked from the samples with forceps under a stereomicroscope. Foraminifera and empty mollusc shells were considered part of the passive sinking flux and hence returned to the main sample, as well as eventual unidentified gelatinous material (e.g. appendicularian houses).

For the analysis of different parameters, samples were divided into several subsamples. Subsampling was done with a McLane WSD 10 splitting device to obtain two fractions of $1 / 10$ and 4/10 each. Of the latter fractions one was used for mass, POC, nitrogen and thorium-234 and one for pigment analysis, and of the former fractions one for faecal pellet and one for microplankton identification.

For mass, POC, $\mathrm{N}$ and ${ }^{234} \mathrm{Th}$ analysis, subsamples were filtered onto a pre-combusted $\left(500^{\circ} \mathrm{C}\right)$ and pre-weighed micro quartz filter (QMF, $\varnothing 25 \mathrm{~mm}$ ). Filters were then dried in an oven at $50^{\circ} \mathrm{C}$. To determine mass flux the dried filters were transferred to a desiccator cabinet for stabilization at room temperature and then weighed on a Mettler Toledo analytical balance. After weighing, these QMF filters were conditioned for ${ }^{234} \mathrm{Th}$ measurement through non-destructive counting of the $\beta$-decay, and that same sample could be used, after dismounting, for the analysis of total carbon and POC. Prior to POC analysis, inorganic carbon was removed from the sample by acidifying twice with a $1 \mathrm{M} \mathrm{H}_{3} \mathrm{PO}_{4}$ solution in excess, the filters being dried at $50{ }^{\circ} \mathrm{C}$ overnight, after each step. POC and $\mathrm{N}$ analysis was performed with a vario EL elemental analyser (Elementar Analysensysteme GmbH) (Miquel et al., 2011). Inorganic carbon was calculated by the difference between total and organic carbon.

The subsamples for pigment analysis (fraction 4/10) were filtered onto a pre-combusted $\left(500^{\circ} \mathrm{C}\right) \mathrm{GF} / \mathrm{F}$ filter $(\varnothing 25 \mathrm{~mm})$ and kept frozen at $-30^{\circ} \mathrm{C}$. For analysis, residue on these fil- 
Table 2. Sampling period and location of long-term sediment traps used to document the seasonal and inter-annual variability (2008-2010) of downward particle fluxes in the vicinity of the drifting stations.

\begin{tabular}{llllll}
\hline Mooring & Sampling starts & Sampling ends & $\begin{array}{l}\text { Latitude } \\
\left({ }^{\circ} \mathrm{N}\right)\end{array}$ & $\begin{array}{l}\text { Longitude } \\
\left({ }^{\circ} \mathrm{W}\right)\end{array}$ & Sampling depth(s) \\
\hline $\mathrm{CA08}$ & 21 Oct 2007 & 24 Jul 2008 & 71.0539 & 126.0227 & $104 \mathrm{~m}$ \\
$\mathrm{CA16}$ & 01 Nov 2007 & 28 Jul 2008 & 71.7904 & 126.4929 & 112 and $213 \mathrm{~m}$ \\
$\mathrm{CA} 05$ & 27 Jul 2008 & 31 Aug 2009 & 71.3125 & 127.5824 & $108 \mathrm{~m}$ \\
$\mathrm{CA16}$ & 29 Jul 2008 & 31 Aug 2009 & 71.7868 & 126.4970 & 110 and $211 \mathrm{~m}$ \\
$\mathrm{~A} 1$ & 21 Jul 2009 & 25 Jun 2010 & 70.7617 & 136.0083 & 98 and $199 \mathrm{~m}$ \\
$\mathrm{G} 09$ & 24 Jul 2009 & 29 Jun 2010 & 71.0025 & 135.4793 & 100 and $201 \mathrm{~m}$ \\
$\mathrm{CA16}$ & 13 Oct 2009 & 16 Oct 2010 & 71.8015 & 126.5170 & 103 and $204 \mathrm{~m}$ \\
$\mathrm{~A} 1$ & 13 Sep 2010 & 31 Aug 2011 & 70.7622 & 136.0094 & 101 and $201 \mathrm{~m}$ \\
\hline
\end{tabular}

ters was extracted by sonication in $3 \mathrm{~mL}$ methanol $(100 \%)$ and clarified by filtration through "Whatman" GF/F filters. Extracts were analysed by HPLC diode array detector ("Agilent Technologies" system) the same day. Chromatography was performed on a narrow reversed-phase C8 Zorbax Eclipse XDB column. Pigment detection was obtained at 450, 667 and $770 \mathrm{~nm}$. Vitamin E acetate ("Sigma") was used as internal standard, and external calibration standards were provided by DHI Water and Environment (Denmark). Details on pigment analysis are reported in Ras et al. (2008).

Both faecal pellets and microplankton were determined by eye under a stereomicroscope. For faecal pellets, a Leica MZ 12 stereomicroscope was used. Absolute numbers of faecal pellets counted were between 25 and 75 per sample. The pellets were sorted into three morphotypes: cylindrical, elliptical and amorphous. Pellet fragments, mostly cylindrical ones, were included in the counts. The dimensions of all pellets were determined with a semi-automated image analysis program, in order to calculate the form-specific volumes. To convert volumes into organic carbon we used a conversion factor of $0.11 \mathrm{mg} \mathrm{C} \mathrm{mm}^{-3}$ (Carroll et al., 1998). Although higher than many values reported in the literature (e.g. Gonzalez et al., 1994; Gonzalez and Smetacek, 1994; Reigstad et al., 2005), this conversion factor represents organism and pellet diversity and, especially, different density levels of the faecal pellets, which is mostly lacking elsewhere. The taxonomic determination down to genus level of microplankton was done according to the Utermöhl method (Utermöhl, 1931). Number of cells counted per sample varied between 10 and 100 and in a few samples between 100 and 1000 .

\subsection{Samples from long-term moorings}

With the aim of putting the results of the Malina study within a broader context, we used a 3-year record of vertical POC fluxes (2008-2010) as sampled with long-term sediment traps moored at ca. 100 and $200 \mathrm{~m}$ depth in the vicinity of the drifting stations (Fig. 1, Table 2) within the framework of the ArcticNet programme. The data from 2009 were reported in detail by Forest et al. (2013), where a full de-

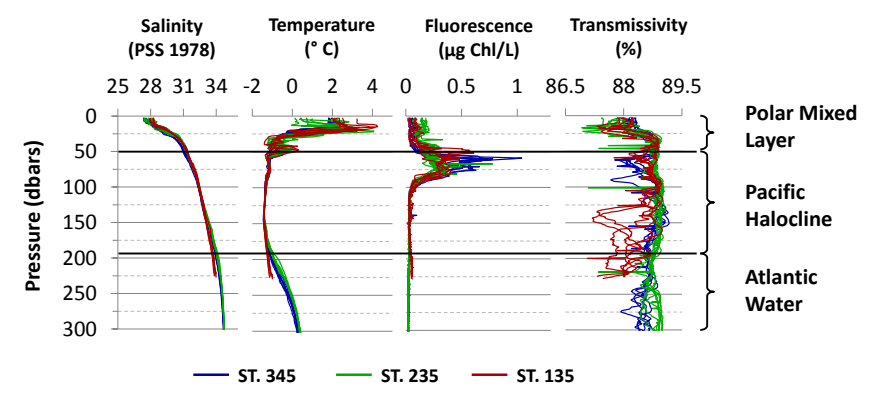

Figure 3. Vertical profiles of salinity, temperature, fluorescence and transmissivity and main water masses at the three sites of drifting trap deployment.

scription of the methodology associated with long-term trap samples can be found. The traps were of the same kind (i.e. TECHNICAP PPS3/3) as those used in the short-term deployment of the present Malina study, though the long-term traps were equipped with a 24 instead of a 12 sample cup carrousel. Otherwise, the design of the trap was exactly the same as the one described in Sect. 2.1. Sample cups from longterm traps were filled with filtered seawater (GFF $0.7 \mu \mathrm{m}$ ) adjusted to 35 salinity with $\mathrm{NaCl}$ and poisoned with formalin (5\% $\mathrm{v} \mathrm{v}^{-1}$, sodium borate buffered). Long-term trap samples were processed (i.e. swimmer picking, fractioning, filtration), weighed for total mass, acidified and analysed for POC and nitrogen, in a similar way to short-term trap samples.

\section{Results}

\subsection{Environmental parameters}

The profiles obtained from the hydrographical casts in the vicinity of the trap deployments show the characteristics of the different water masses present in the Beaufort Sea with only minor variations between the three deployment sites (Fig. 3). 


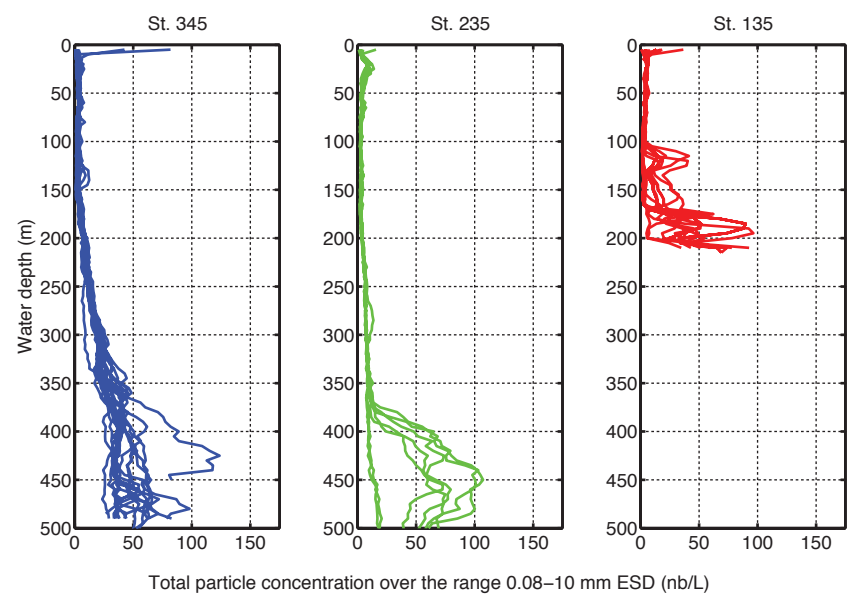

Figure 4. Vertical profiles of total particle concentration (in the size range $0.08-10 \mathrm{~mm}$, in equivalent spherical diameter, ESD) measured at the drifting mooring sites and obtained with multiple deployments of the Underwater Vision Profiler 5.

Salinity values $<31$ were measured in the upper $50 \mathrm{~m}$ and are typical of the PML water. Between 50 and $200 \mathrm{~m}$ depth the salinity increases from 31 to 34 , while the temperature profiles show minimum values. This water mass originates from the Pacific and enters the Arctic Ocean through the Bering Strait into the Chukchi Sea. The fluorescence maxima were mostly found at the top of this water layer around $75 \mathrm{~m}$ depth. Transmissivity measured at all three sites did not exhibit any clear pattern, except for generally low values near the surface and an increased variability near the bottom, between profiles at site 135 . The waters below $200 \mathrm{~m}$ depth are of Atlantic origin and are characterized by the highest salinity (>34) and a warming of the water temperature compared to the overlying waters.

Based on UVP5 data, the upper water column $(<100 \mathrm{~m})$ at all three sites was particularly devoid of particulate material and aggregates in the range $0.08-10 \mathrm{~mm}$ ESD (Fig. 4). We detected a general augmentation in particle inventory within the interval depth of $\sim 350-500 \mathrm{~m}$ at sites 345 and 235 , and between $\sim 100-200 \mathrm{~m}$ at site 135 (as seen in the transmissivity signal, Fig. 3). However, the magnitude of those increases varied markedly between each CTD-UVP5 deployment and some profiles did not show any increase at all.

\subsection{Flux and composition of settling particles}

Mass fluxes measured at the three sites showed different depth patterns (Fig. 5). Although the flux increase from 40 to $85 \mathrm{~m}$ was common to all sites, only site 135 showed an increase from 85 to $150 \mathrm{~m}$ depth, while at the two other sites, the flux decreased. The fluxes at $150 \mathrm{~m}$ of sites 345 and 135 were respectively the lowest and highest ones registered at each site. The high value of site 135 is possibly due to effects of matter resuspension, the trap being just $70 \mathrm{~m}$ above
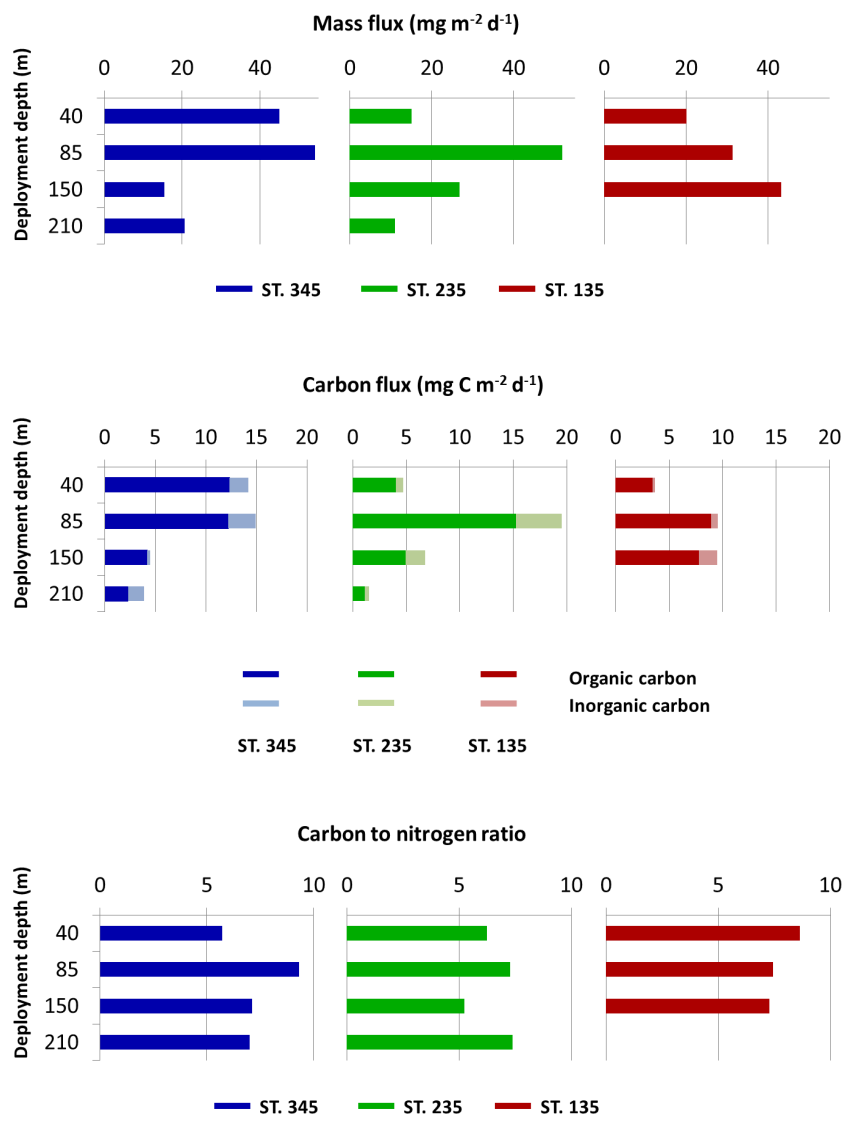

Figure 5. Downward flux of mass, particulate carbon (POC, PIC and TC, the sum of both) and carbon : nitrogen molar ratio obtained from drifting sediment trap moorings. Colours correspond to sites in Fig. 1.

the ocean bottom (Table 1). The overall highest mass fluxes of 54.20 and $51.94 \mathrm{mg} \mathrm{m}^{-2} \mathrm{~d}^{-1}$ at $85 \mathrm{~m}$ of sites 345 and 235 , respectively, were observed just below the depth of relatively high phytoplankton biomasses shown by the fluorescence profiles in Fig. 3.

The vertical distribution of the total carbon fluxes was similar to the mass fluxes, with highest values (15$20 \mathrm{mg} \mathrm{C} \mathrm{m}^{-2} \mathrm{~d}^{-1}$ ) at $85 \mathrm{~m}$ and a sharp decrease in flux towards depth, except for site 135 where the trap near to the bottom recorded a relatively high flux of $9.51 \mathrm{mg} \mathrm{C} \mathrm{m}^{-2} \mathrm{~d}^{-1}$. At $210 \mathrm{~m}$ depth of the two other sites, fluxes were lowest $\left(<5 \mathrm{mg} \mathrm{C} \mathrm{m}^{-2} \mathrm{~d}^{-1}\right)$.

POC fluxes, too, showed depth distributions very similar to mass and total carbon. This suggests a relationship between mass and carbon fluxes, and that the composition of the biotic compartment of the flux seemed to be similar all over the studied area. Also, the contribution of POC to total carbon was high owing to similar flux values up to $15 \mathrm{mg} \mathrm{m}^{-2} \mathrm{~d}^{-1}$ for the maximum at $85 \mathrm{~m}$ of site 235 and $<2 \mathrm{mg} \mathrm{m}^{-2} \mathrm{~d}^{-1}$ at $210 \mathrm{~m}$. Generally, POC fluxes were low with values mostly $<5 \mathrm{mg} \mathrm{m}^{-2} \mathrm{~d}^{-1}$. Higher fluxes were observed just below the 
Table 3. Mass flux (DW) and composition of sedimenting particles.

\begin{tabular}{|c|c|c|c|c|c|c|c|c|c|c|c|}
\hline \multirow{2}{*}{$\begin{array}{l}\text { Sampling stations } \\
\text { Sampling depths (m) }\end{array}$} & \multicolumn{4}{|c|}{345} & \multicolumn{4}{|c|}{235} & \multicolumn{3}{|c|}{135} \\
\hline & 40 & 85 & 150 & 210 & 40 & 85 & 150 & 210 & 40 & 85 & 150 \\
\hline Mass flux $\left(\mathrm{mg} \mathrm{m}^{-2} \mathrm{~d}^{-1}\right)$ & 45 & 54 & 15 & 21 & 15 & 52 & 27 & 11 & 20 & 31 & 43 \\
\hline Tot. carbon (TC) (\% of DW) & 31 & 28 & 29 & 19 & 31 & 38 & 25 & 14 & 18 & 31 & 22 \\
\hline Org. carbon (\% of DW) & 27 & 23 & 27 & 11 & 27 & 29 & 18 & 10 & 17 & 28 & 18 \\
\hline Inorg. Carbon (\% of DW) & 4.1 & 5.0 & 1.8 & 7.7 & 4.6 & 8.3 & 6.9 & 3.5 & 1.2 & 2.1 & 4.0 \\
\hline Org. carbon (\% of TC) & 87 & 82 & 94 & 59 & 85 & 78 & 73 & 74 & 94 & 93 & 82 \\
\hline Nitrogen (\% of DW) & 5.6 & 2.8 & 4.5 & 1.9 & 5.0 & 4.7 & 4.1 & 1.6 & 2.3 & 4.5 & 2.9 \\
\hline $\mathrm{C}: \mathrm{N}$ atomic & 5.7 & 9.3 & 7.1 & 7.0 & 6.2 & 7.3 & 5.2 & 7.4 & 8.7 & 7.4 & 7.3 \\
\hline$C_{\text {inorg }}: C_{\text {org }}$ & 0.15 & 0.22 & 0.06 & 0.69 & 0.17 & 0.28 & 0.37 & 0.35 & 0.07 & 0.07 & 0.22 \\
\hline
\end{tabular}

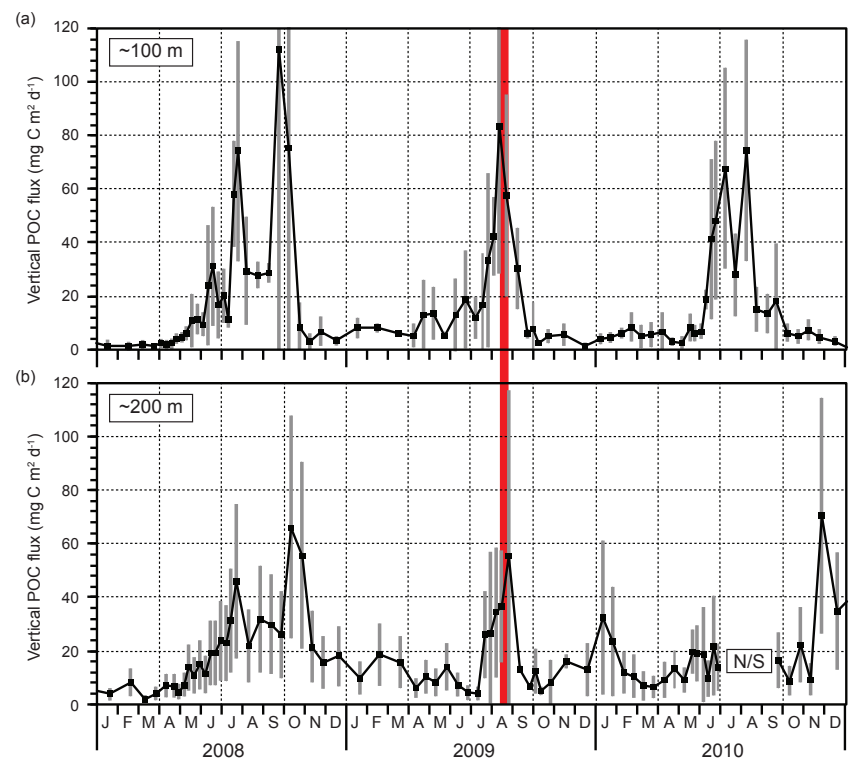

Figure 6. Time series of mean downward POC fluxes as measured at (a) $\sim 100 \mathrm{~m}$ and (b) $\sim 200 \mathrm{~m}$ with the ArcticNet sequential sediment traps (A1, G09, CA05, CA08 and CA16) moored in the vicinity of the drifting stations (see Fig. 1, Table 2). Vertical grey bars depict the standard deviation associated with each mean POC flux data point. The vertical red bar delimits the third week of August 2009 when short-term traps were deployed. N/S: no sampling.

biomass maximum, and also at $40 \mathrm{~m}$ of site 345 and near the bottom of site 135 .

The flux pattern of inorganic carbon, essentially calcium carbonates, was quite similar to the one of mass flux, but about 1 order of magnitude lower. As for POC, this shows that the biotic component of the vertical flux was relatively homogeneous over the studied area. The only notable difference in the vertical flux pattern between total and organic carbon on the one hand and mass and inorganic carbon on the other hand concerns the results from the deepest traps at sites $345(210 \mathrm{~m})$ and $135(150 \mathrm{~m})$, where fluxes of both mass and inorganic carbon were higher than at the above sampling depths. This is most likely due to the vicinity of these two traps to the bottom where resuspended matter including inorganic carbon may have been added to the vertical flux. This shows that the resuspended material was mainly of abiotic origin. Interestingly, at site 235 , where all components of the flux, mass, total, organic and inorganic carbon decreased from $150 \mathrm{~m}$ to $210 \mathrm{~m}$, the deepest trap was the furthest away from the bottom among the moorings at the three sites (Table 1).

The $\mathrm{C} / \mathrm{N}$ ratios did not show big variations within and between the three sites, neither could we observe any clear depth pattern. But the obtained ratios are above the Redfield ratio, a finding that was already reported by Schneider et al. (2003) from a global data set of sediment trap samples (0$500 \mathrm{~m})$. This study showed that the average $\mathrm{C} / \mathrm{N}$ ratio (8.55, \pm 3.58 (SD), $n=744$ ) was significantly above the Redfield ratio despite the high variability of values in the data set.

The composition of the particles collected in the sediment traps (Table 3 ) revealed for almost all the samples a very high content of POC relative to total carbon with values often exceeding $80 \%$ or even $90 \%$. Only at site 235 , these values were lower, just slightly below $80 \%$. But also the POC content relative to the mass flux was rather high. The obtained values were between 23 and $29 \%$ for the traps at 40 and $85 \mathrm{~m}$ with one exception (17\% at $40 \mathrm{~m}$, site 135$)$, but decreased to 10 and $11 \%$ in the traps at $210 \mathrm{~m}$ of sites 345 and 235.

The importance of inorganic carbon (PIC) relative to total carbon was, unlike POC, rather low at the surface and high at depth. The PIC/POC ratio, in turn, was relatively high in the deep traps ( 150 and $210 \mathrm{~m}$ ) except at $150 \mathrm{~m}$ of site 345 where very low amounts of PIC were measured.

\subsection{Seasonal and inter-annual variability of downward flux}

Using the long-term trap data sets (cf. Forest et al., 2013) available for the region from 2008-2010 (Table 2), we have created a composite time-series of mean POC fluxes at $\sim 100$ and $\sim 200 \mathrm{~m}$ depth (Fig. 6). This figure enables us to grasp quickly the seasonality and large variability (i.e. SD) of downward POC fluxes across the eastern Mackenzie Shelf. Over those years, mean POC fluxes oscillated between near- 
Table 4. Faecal pellet flux (numerical and carbon) and relative contribution of each type of pellet to the total numerical flux. Note: different units for pellet flux (mg and $\mu \mathrm{g})$.

\begin{tabular}{|c|c|c|c|c|c|c|c|c|c|c|c|}
\hline \multirow{2}{*}{$\begin{array}{l}\text { Sampling stations } \\
\text { Sampling depths (m) }\end{array}$} & \multicolumn{4}{|c|}{345} & \multicolumn{4}{|c|}{235} & \multicolumn{3}{|c|}{135} \\
\hline & 40 & 85 & 150 & 210 & 40 & 85 & 150 & 210 & 40 & 85 & 150 \\
\hline $\begin{array}{l}\text { Pellet flux (all pellets) } \\
\left(\mathrm{mg} \mathrm{C}_{\text {org }} \mathrm{m}^{-2} \mathrm{~d}^{-1}\right)\end{array}$ & 1.32 & 0.45 & 0.77 & 0.92 & 0.22 & 0.34 & 0.44 & 0.27 & 0.66 & 0.25 & 0.82 \\
\hline $\begin{array}{l}\text { Pellet flux (only } 100 \% \text { full pel- } \\
\text { lets) }\left(\mu \mathrm{g} \mathrm{C} \mathrm{Corg} \mathrm{m}^{-2} \mathrm{~d}^{-1}\right)\end{array}$ & 17.4 & 7.6 & 439.8 & 670.0 & 0.0 & 2.7 & 362.3 & 220.4 & 0.7 & 0.0 & 424.2 \\
\hline $\begin{array}{l}\text { Numerical flux (all pellets) } \\
\left.\text { (nb. } \mathrm{m}^{-2} \mathrm{~d}^{-1}\right)\end{array}$ & 4680 & 2880 & 1920 & 3120 & 806 & 2342 & 2458 & 960 & 4389 & 2057 & 4663 \\
\hline Cylindrical pellets (\%) & 56.4 & 52.1 & 18.8 & 11 & 52.4 & 62.3 & 9.4 & 20.0 & 85.9 & 53.3 & 22.1 \\
\hline & & 35. & 56.3 & 40.4 & 47.6 & 32. & 76. & 60 & 14.1 & 46.7 & 69.1 \\
\hline Amorphous pellets (\%) & 11.5 & 12.5 & 25.0 & 48.1 & 0.0 & 4.9 & 14.1 & 20.0 & 0.0 & 0.0 & 8.8 \\
\hline
\end{tabular}

zero values up to $\sim 110 \mathrm{mg} \mathrm{Cm}^{-2} \mathrm{~d}^{-1}$. In general, POC fluxes were higher at 100 than at $200 \mathrm{~m}$ depth, except during the winter months when the background flux was higher at 200 than at $100 \mathrm{~m}$ depth. Peak fluxes (from 1-3 modes) occurred systematically over the summer period, but rapid declines were detected after every one of those maxima. In 2009, the peak export flux (as detected at the 4 moorings deployed across the region) was recorded over August, during the month of the Malina campaign. However, the standard deviation associated with the values measured during the peak period in 2009 as well as in the other years was particularly high at both 100 and $200 \mathrm{~m}$ depth.

\subsection{Particle characterization}

\subsubsection{Faecal pellets}

Apart from microplankton cells, the main types of identifiable particles in the sediment trap samples are shown in Fig. 7. Most of these particles were faecal pellets of cylindrical or elliptical form (Fig. 7a-d). A third category that was distinguished contained amorphous pellets. Also, notable numbers of crustacean eggs (Fig. 7e) and foraminifera (Fig. 7f) were observed. Total numbers and the relative importance of the different types of faecal pellets are listed in Table 4. Flux of the total number of pellets showed two distinct vertical patterns. At sites 345 and 135, high numbers were recorded at the surface and in the deepest traps, and at site 235, this pattern was reversed with the lowest numbers at surface and bottom. Cylindrical pellets were most important at 40 and $85 \mathrm{~m}$ depth at all sites and elliptical ones were present at relatively higher numbers in the deepest traps (150 and $210 \mathrm{~m}$ ), especially at site 235 . The absolute numbers of cylindrical pellets but also their relative importance are slightly overestimated owing to the fragmented pellets included in the counts. We accepted this bias in favour of the more important pellet carbon content, which is more precise when fragments are included. Amorphous pellets were gen-
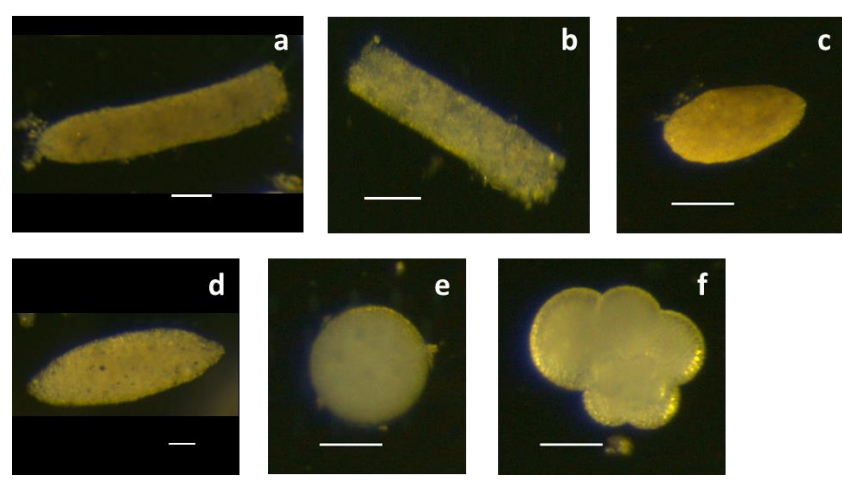

Figure 7. Faecal pellets (a-d), fish eggs (e) and foraminifera (f) present in sediment traps. The two main morphotypes of pellets, cylindrical, produced by large calanoid copepods, and elliptical, produced by small cyclopoid copepods (c) and appendicularians (d), are shown at two different levels of fullness: cylindrical pellets (a full, b partly filled), elliptical pellets (c full, d partly filled). White bar is $100 \mu \mathrm{m}$.

erally observed at relatively low numbers and were absent at 40 and $85 \mathrm{~m}$ of site 135 and at $40 \mathrm{~m}$ of site 235 .

The different forms of the faecal pellets were taken into account when calculating their organic carbon content (Carroll et al., 1998). Another outstanding feature was the density of the matter inside the pellet membrane, as illustrated in Fig. 7a-d. Across the sampling sites, there was a clear spatial pattern in the relative importance of faecal pellets with different matter density. As an example, the pellets considered as full (highest matter density) were essentially observed at 150 and $200 \mathrm{~m}$ depth at all sites. Since the conversion factors for the calculation of the organic content are based on full pellets (Fig. 7a and c) we defined four empirical categories of fullness, $100,75,50$ and $25 \%$, and corrected the conversion factors accordingly. The resulting flux of organic carbon channelled via faecal pellets is listed in Table 4, which also shows the carbon flux attributed to full $(100 \%)$ pellets. While the depth distributions of the pellets' carbon flux resemble the 


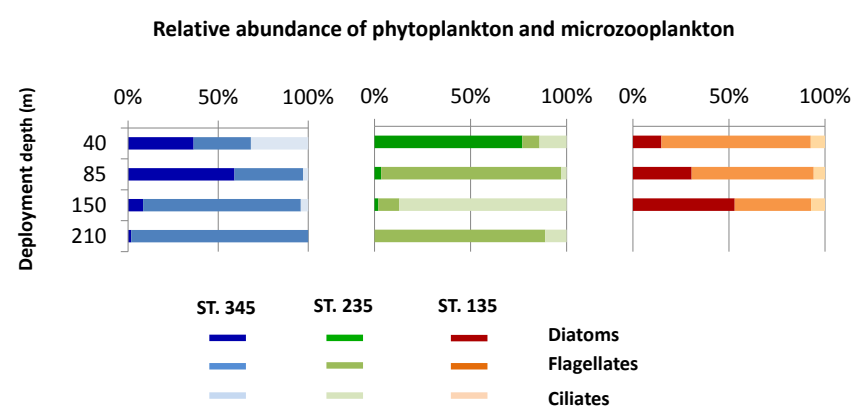

Figure 8. Relative abundance of phyto- and microzooplankton in the sediment traps at the different deployment depths. The identified taxa were grouped into diatoms, flagellates and ciliates.

numerical flux with an inverse pattern at site 235 compared to the two other sites, full pellets were only observed at 150 and $210 \mathrm{~m}$ depth. But they represent about 50 to $80 \%$ of the total pellet flux. Overall, the carbon channelled through the flux of faecal pellets represented from a few percent up to $25 \%$ of the total carbon flux, especially in the deepest traps.

\subsubsection{Phytoplankton and microzooplankton}

The recognizable particles other than faecal pellets were protist cells which were counted and identified to genus level. This identification revealed a near absence of large sized diatoms (e.g. Chaetoceros sp., Thalassiosira sp.), which are commonly found in polar regions (Coupel et al., 2015; Lovejoy et al., 2002). Among the diatoms observed, the epiphytic genus Licmophora was the most abundant one. Flagellates, especially the dinoflagellate Pronoctiluca often showed high abundances, and only in a few traps, some tintinnids (loricate ciliates) and naked ciliates were important.

The identified taxa were classified into three groups, diatoms, flagellates and ciliates, of which the relative abundance in each sample is shown in Fig. 8. At site 345, the dominant groups were flagellates and diatoms, the former group being mainly composed of dinoflagellates, and the latter of the genus Licmophora. Ciliates were present at all but one depth but at low relative abundance, except at $40 \mathrm{~m}$ where they reached $32 \%$. At site 235, microzooplankton (dinoflagellates and ciliates) were most abundant and diatoms were relatively important at $40 \mathrm{~m}$ depth. Similar to site 345 , diatoms and flagellates showed highest relative abundances at site 135 , while ciliates represented $<10 \%$. At $150 \mathrm{~m}$, the percentage of diatoms $(53 \%)$ was the highest of all three sites.

\subsubsection{Pigment composition}

The results of the pigment analysis in the sediment trap samples are presented as concentrations (ng mg ${ }^{-1}$ POC or ppm, Table 5). The POC flux being generally low (Fig. 5), many pigments were below detection limits. Only pigments de-
Table 5. Concentration of major pigments in sedimenting particles at the three mooring sites (in $\mathrm{ng} \mathrm{mg}^{-1}$ POC).

\begin{tabular}{lllll}
\hline \multicolumn{2}{c}{ Sampling stations } & 345 & 235 & 135 \\
\hline \multirow{4}{*}{$80 \mathrm{~m}:$} & Total Chl $a$ & 5.6 & 76.3 & n.d. \\
& Astaxanthin & 7.8 & 87.1 & 138.3 \\
& Total Chl $a$ & 185.5 & 393.4 & 562.8 \\
& Total Chl $b$ & 26.7 & 61.4 & 42.2 \\
& Fucoxanthin & 35.5 & 36.0 & 179.6 \\
& Prasinoxanthin & 26.4 & 52.4 & 42.7 \\
& Astaxanthin & 66.4 & 72.1 & n.d. \\
& Phaeophytin $a$ & 15.3 & 13.4 & 23.1 \\
$150 \mathrm{~m}:$ & Total Chl $a$ & - & 303.2 & 432.2 \\
& Total Chl $b$ & - & 32.7 & 42.7 \\
& Fucoxanthin & - & 86.9 & 182.8 \\
& Prasinoxanthin & - & 26.6 & 46.5 \\
& Astaxanthin & - & 23.5 & n.d \\
& Phaeophytin $a$ & - & 24.9 & 26.9 \\
210 m: & Total Chl $a$ & n.d. & 405.9 & - \\
& Total Chl $b$ & n.d. & 62.7 & - \\
& Fucoxanthin & n.d. & 67.9 & - \\
& Prasinoxanthin & n.d. & 80.1 & - \\
Astaxanthin & n.d. & 29.6 & - \\
& Phaeophytin $a$ & n.d. & 43.5 & - \\
\hline n.d. $=$ not detected (below detection limit); $-=$ not sampled or measured. &
\end{tabular}

tected in most of the trap samples are presented. One pigment, Peridinin, was observed at all sites but only in the $85 \mathrm{~m}$ traps, plus once at $40 \mathrm{~m}$ of site 235 .

At site 345, highest concentrations were measured for $\mathrm{Chl} a$ at $85 \mathrm{~m}$ depth. The presence of phytoplanktonic material is contrasted by relatively high concentrations of Astaxanthin, which is rather an indicator for zooplankton. These two pigments were the only ones detected in the shallowest trap at $40 \mathrm{~m}$.

The same observations were made at site 235 , although the concentrations of the two pigments at $40 \mathrm{~m}$ were much higher. In the deeper traps, besides the high $\mathrm{Chl} a$ concentrations, Fucoxanthin at $150 \mathrm{~m}$ and also Prasinoxanthin at $210 \mathrm{~m}$ showed relatively high concentrations. The increasing concentrations with depth of Phaeophytin at this site indicate the increase of the relative importance of phytoplankton degradation.

At site 135, Chl $a$ was still observed at very high concentrations except in the shallowest trap where it was not detectable. Fucoxanthin, however, was much more abundant than at the other sites and its concentration even slightly increased between 85 and $150 \mathrm{~m}$. Fucoxanthin being a typical pigment of diatoms (Wright and Jeffrey, 1987), this could correspond to the increase in the relative importance of diatoms observed before (see Sect. 3.4.2).

\subsubsection{Swimmers}

Swimmers were abundant in sediment trap samples, particularly at the two shallowest sampling horizons. A dedicated 
study on the swimmers collected in the sediment traps will be published elsewhere and only a summary is offered here.

Copepods were by far the most abundant group among the swimmers' community. In all traps they represented more than 75 and up to $95 \%$ of the total abundance. Among the other groups, only appendicularians (mostly Oikopleura spp.) and pelagic molluscs (essentially Limacina helicina) were observed at notable numbers. The relative depth distribution of the different organisms was similar at all sites. In the shallow traps $(40 \mathrm{~m})$, a herbivorous copepod (Calanus glacialis) and appendicularians (Oikopleura spp.) represented 40 to $70 \%$ of all swimmers present. In the traps below the phytoplankton biomass maximum at $85 \mathrm{~m}$, the absolute number of swimmers was about twice as much as that from $40 \mathrm{~m}$ depth, and the omnivorous copepod Metridia longa was by far the most abundant swimmer organism (60$75 \%$ ). Among the other organisms found at $85 \mathrm{~m}$ depth, the herbivorous pteropod Limacina helicina was present at all sites. In the deepest traps at $150 \mathrm{~m}$ (all sites) and $210 \mathrm{~m}$ (sites 345 and 235) the absolute number of swimmers decreased five to ten fold relative to the shallower traps. The omnivorous Metridia longa became even more important, but the carnivorous copepod Pareuchaeta glacialis represented 15$25 \%$ of the swimmers at $150 \mathrm{~m}$ depth of sites 235 and 135 . This copepod was also present in all other traps at percentages between 10 and $15 \%$, except at site 345 where it was absent at $150 \mathrm{~m}$ and represented $25 \%$ at $85 \mathrm{~m}$. The only herbivore swimmers observed in these deepest traps were $\mathrm{Li}$ macina helicina (150 m, sites 235 and 135) and Calanus hyperboreus (150 and $210 \mathrm{~m}$, site 235 ).

\section{Discussion}

Sediment trap moorings anchored at the ocean floor on a long-term basis have a relatively long history in arctic research (Honjo et al., 2008 and reference therein). However, the deployment of drifting sediment trap moorings in the Beaufort Sea was part of only a few oceanographic expeditions. This is most likely due to the ice conditions not favourable to such deployments during most of the year and over a vast area, while for fixed moorings, ice conditions are only critical during deployment and retrieval. An indirect method based on the deficit between the particle reactive ${ }^{234} \mathrm{Th}$ and its conservative parent radionuclide ${ }^{238} \mathrm{U}$ (Rutgers van der Loeff et al., 2006) is better adapted to these conditions and was used in various studies to assess the vertical POC flux in the Arctic seas (Wassmann et al., 2004).

When comparing our results with the published data from the same region and at similar depths, we notice that the POC fluxes we measured were always at the lower end of the broad range of fluxes reported, which spans from some $10 \mathrm{mg} \mathrm{C} \mathrm{m}^{-2} \mathrm{~d}^{-1}$ to a few hundred $\mathrm{mg}$ of carbon per $\mathrm{m}^{2}$ and per day. Such was the case for the studies using drifting trap moorings (Juul-Pedersen et al., 2010; Lalande et al., 2007;
Sallon et al., 2011) as well as for the ones obtained via the ${ }^{234} \mathrm{Th} /{ }^{238} \mathrm{U}$ disequilibrium (Baskaran et al., 2003; Lalande et al., 2007; Moran and Smith, 2000).

Temporal and spatial variabilities have been given special attention in studies undertaken in the Barents Sea and surrounding areas (Wassmann et al., 2006; Wassmann, 2011; Reigstad et al., 2011) where the receding ice edge is at the origin of production and subsequent vertical flux pulses, which together with an uneven bottom morphology and hydrological factors lead to a highly variable environment (Reigstad et al., 2011). While these factors probably play a role in the annual and seasonal variabilities and also in spatial heterogeneities occurring within the Beaufort-Mackenzie continental margin, their interplay results in different production and flux regimes. The seasonal ice zone covers not only the Mackenzie shelf but also the deep Canadian basin and the hydrological environment is also different from the one observed in the Barents Sea. Limited input of nutrients to the euphotic layer and episodical inputs from the shelf edge together with upwelling events are the relevant factors for the variabilities observed in this area. They are ultimately at the origin of the flux differences between the present study and the published data. Another possible factor of variability is the trap design, which in our case was different from the above mentioned studies, in particular the collecting surface. However, in the present study the same type of sediment traps was used for both drifting and fixed moorings, and were both used for sampling in the same region and during the Malina campaign (Tables 1,2). Nevertheless, the traps of the two moorings are likely to collect different amounts of particle flux due to spatial heterogeneities and also due to the hydrodynamic environment. A fixed mooring is exposed to water currents, but not so a drifting mooring as the adjective indicates, although it appears that the direction of the drifting path sometimes differs from the current direction. In order to minimize collection biases, trap moorings should be deployed in tranquil regions and the aspect ratio of the traps should be 3 for water currents $<10 \mathrm{~cm} \mathrm{~s}^{-1}$ and higher if water currents are expected to increase (Knauer and Asper, 1989). Current speeds at the fixed moorings site of this study were $<10 \mathrm{~cm} \mathrm{~s}^{-1}$ (Forest et al., 2013) and the aspect ratio of the traps was 2.5 in the cylindrical part and 4 for the overall length. We would therefore expect a minimum collection bias for both mooring types. Still, Forest et al. (2011) showed in a similar study that the fluxes measured with short-term drifting traps were always higher than those with the long-term fixed traps, but the collecting surfaces were different between the two mooring types.

The present study revealed the opposite situation with the POC fluxes recorded by the short-term traps being relatively low compared to the long-term traps (Fig. 6). But as we already mentioned, the data of these latter traps are shown as a composite figure and the standard deviation is particularly high during the peak flux periods, while it is low during low flux regimes although we would expect not only spatial 
heterogeneities related to the distance between the different mooring locations, but also temporal variabilities between sampling years. Since we observed no spatial nor temporal trend in the flux differences during the peak periods, which occurred at all mooring sites, the high standard deviation reflects a general variability of the vertical particle flux during these periods. The 2009 period in particular was reported by Forest et al. (2013), who discussed these data in more detail and recalled us the fact that the "peak fluxes were presumably linked to episodic sinking flux events". With respect to our data, we consider that, although the late summer months seem to be a period of an elevated flux regime (Forest et al., 2013), the vertical particle flux monitored by our traps during $<3$ days is situated between or around these episodic flux pulses. From the data recorded by the particle camera (UVP5) we know at least that at that time, the particle load of the water column along the drifting path was very low (Fig. 4).

If the flux quantity is an important factor of carbon cycling in terms of, e.g., parameterization and validation of models, the flux quality is just as important when it comes to conceptualization of models (Le Fouest et al., 2013). The composition of the particulate matter collected in our sediment traps is characterized by both a relatively high total carbon content (average $26 \pm 7 \%$ ) and a high $C_{\text {org }}$ to $C_{\text {tot }}$ ratio. This indicates that an important part of the settling particles is of biogenic origin and that these particles contain relatively small amounts of calcium carbonates. It also explains that highest fluxes were observed just below the depth layer of maximum phytoplankton biomass (Figs. 3 and 5) and underlines that the decrease at depth of the organic carbon content in the particles settling further down the water column is due to remineralization (Table 3). However, these results suggest that the Mackenzie River plume seems to have little or no influence on the particle composition at the drifting trap locations. Surface POC concentrations obtained through satellite image processing from the sampling period confirm this observation (Forest et al., 2013). We also do not expect any influence of the high $\mathrm{C} / \mathrm{N}$ ratio $(>10)$ in river water particles (Emmerton et al., 2008) on our trap material, although the ratios we measured did not indicate any spatial trend. Such was the case in the traps of the long-term series (Forest et al., 2013), too. A study by Tamelander et al. (2013) in the European Arctic Ocean reported $\mathrm{C} / \mathrm{N}$ ratios well above the Redfield ratio and suggested that the ratios varied according to new production, which depended on the nitrate availability and thus the trophic state of a given ecosystem. Other studies put forward the increase of the $\mathrm{C} / \mathrm{N}$ ratio with depth (CopinMontégut and Copin-Montégut, 1983; Schneider et al., 2003) related to preferential remineralization of nitrogen. There is insufficient consistency in both the data of the present study and the data of the long-term study (Forest et al., 2013) to be able to relate them to any of the findings reported in those previous studies, but at least they confirmed that the $\mathrm{C} / \mathrm{N}$ ratio of trap samples is above the classical Redfield ratio.
Faecal pellets form a well-distinct and sometimes major part of the sinking particles in the Beaufort Sea area (Forest et al., 2008; Juul-Pedersen et al., 2010). The quantitative distributions of total pellets in the present study, be it numerically or in terms of carbon, indicate at sites 345 and 135 relatively high grazing activities above the trap at $40 \mathrm{~m}$ depth and above the deepest trap at 210 and $150 \mathrm{~m}$, respectively (Table 4). Lowest quantities at these sites in terms of carbon were observed in the samples from $85 \mathrm{~m}$ just below the phytoplankton biomass maximum. This is in contrast to the findings by Forest et al. (2012), who found good agreement between maximum phytoplankton abundance and copepods, which were by far the most abundant grazers around $60 \mathrm{~m}$ depth. It follows that, either grazing activity at this depth was low despite the relatively high food availability or the produced pellets were subject to enhanced coprophagy and/or coprohexy (Svensen et al., 2014), a process, which has already been reported from the nearby Baffin Bay (Sampei et al., 2004) and which we cannot exclude although we do not have direct evidence. Another possibility for this observation could be that defecation from these grazers took place above the $40 \mathrm{~m}$ depth horizon. A detailed study on copepod migration in the Beaufort Sea (Darnis and Fortier, 2014) did not show evidence of diel but rather seasonal vertical migration, which does not explain an eventual short-term displacement observed in our study. However, Cottier et al. (2006) describe an unsynchronized migration by large calanoid copepods, which took place at around the same period of the year in an arctic fjord. We do not have data to confirm such behaviour. However, our data showed that at $40 \mathrm{~m}$ the pellet fluxes were highly variable across the three sites, but were much less variable at $85 \mathrm{~m}$. We therefore do not exclude the possibility that the depth distributions at sites 345 and 135 are due to this high variability observed at $40 \mathrm{~m}$. Nonetheless, the pellet flux did not have a considerable impact on the total carbon flux distribution in the euphotic zone, since it represented $<10 \%$, except at $40 \mathrm{~m}$ of site 135 , where a lower pellet flux would accentuate the discrepancy of the carbon flux between 40 and $85 \mathrm{~m}$ depth.

The decrease of faecal pellet flux from the surface to $85 \mathrm{~m}$ depth just below the phytoplankton maximum (except at site 235) and especially the increase at $150 \mathrm{~m}$ (sites 235 and 135 ) and $210 \mathrm{~m}$ (site 345) can best be explained by the qualitative features of the faecal particles. The relative contribution of the two major morphotypes, cylindrical and elliptical pellets, was high in the two upper traps for the former and in the lower traps for the latter ones, or in other words, the vertical flux patterns of these morphotypes were inversed. This implies, on the one hand, that cylindrical pellets are less produced at greater depths and that the sinking pellets from the upper layers are degraded and remineralized before reaching these depths (Honjo et al., 2010). On the other hand, there is a production of elliptical pellets below the trap at $85 \mathrm{~m}$ and/or elliptical pellets produced above are more refractory 
than cylindrical ones and are therefore sampled by the traps at greater depths.

Cylindrical pellets are mainly produced by large calanoid copepods (Carroll et al., 1998; Yoon et al., 2001), which were indeed the most abundant zooplankton observed in surface waters at this period of the year in the Beaufort Sea (Forest et al., 2012), but also elsewhere in the Arctic Ocean (Daase et al., 2008; Kosobokova and Hirche, 2000; Kosobokova and Hopcroft, 2010; Thor et al., 2005). Without any experimental evidence it is difficult to attribute a given type and size of pellets to a certain organism. The cylindrical pellets in our samples were between 40 and $170 \mu \mathrm{m}$ wide (mean: $88 \pm 19 \mu \mathrm{m}$ (SD), $n=224$ ), which is within published ranges for large calanoid copepods (Sampei et al., 2009; Wexels Riser et al., 2008). Although we cannot exclude the presence of at least fragments of cylindrical pellets produced by euphausiids, the pellets in our samples did not show typical characteristics of these pellets (irregular cylindrical shape, filiform, colour differences, etc., see also Wexels Riser et al., 2002; Wilson et al., 2008). Moreover, we did not observe them as swimmers or their fragments as passive flux in our trap samples, and they were not reported from zooplankton observations made during the same study (Forest et al., 2012).

The smaller elliptical faecal pellets are attributed to small copepods, but also to appendicularians (Carroll et al., 1998; Yoon et al., 2001). While for the cylindrical pellets we had at least indirect evidence for potential producers of the pellets (see Sect. 3.4.4 swimmers), for the elliptical pellets we had only evidence for appendicularians but not for smaller copepods. Again, we can only speculate on the origin of elliptical pellets observed in our samples. Their mean width was $115 \pm 43 \mu \mathrm{m}$ (SD), $n=236$ (range: 44-282 $\mu \mathrm{m}$ ). Some values reported from the literature are the following: $100 \mu \mathrm{m}$ (Beaumont et al., 2001), 30-100 um (Gonzalez et al., 1994) and $<60 \mu \mathrm{m}$ (Sampei et al., 2009). This puts the size of the pellets in our samples at the high end of previously measured values. It is, however, clearly below the width size range $(250-900 \mu \mathrm{m})$ of some values reported for elliptical pellets produced by appendicularians (Deibel and Turner, 1985; Lombard et al., 2013; Wexels Riser et al., 2008). We assume therefore that most of the elliptical pellets in our samples originate from small copepods, e.g., cyclopoids. However, given the size range of the pellets in our study, the bigger-sized ones were probably produced by appendicularians (Fig. 7d). The example in Fig. 7d matches well the description given by Wilson et al. (2013): “The ellipsoid pellets... were slightly pointed on both ends and readily recognizable as larvacean fecal pellets." Forest et al. (2012) reported cyclopoid copepods of the genera Oncaea, Triconia and Oithona as being among the most abundant copepods in the study area. Together with the small calanoid copepod genus, Microcalanus, they represented close to $70 \%$ of the zooplankton assemblage caught by a plankton net. Also, Oncaea is well known to dwell in and to be adapted to the meso- and bathypelagic zone below the euphotic layer
(Kosobokova and Hopcroft, 2010; Thor et al., 2005). Individuals of the genus Triconia, too, tend to occupy mesopelagic depths (Kosobokova and Hopcroft, 2010), while Oithona and Microcalanus seem to have a preference for shallower depths even if they can be found over almost the entire water column (Kosobokova and Hopcroft, 2010). Although appendicularians were most abundant above $100 \mathrm{~m}$ depth during the study (Forest et al., 2012), we observed large elliptical pellets in all our traps, but they were too scarce to detect any depth pattern.

We cannot exclude that the elliptical faecal pellets produced at shallow depths reach the deeper traps at 150 and $210 \mathrm{~m}$. We know, however, that this production was of minor importance compared to the cylindrical pellets. Also, given the relative as well as absolute increase in abundance towards the trap at $145 \mathrm{~m}$, elliptical faecal pellets are produced at greater depths, most likely by cyclopoid copepods. The depth distribution of the swimmers in our traps corroborates these findings, though not quantitatively but with respect to the planktonic feeding regimes. Large herbivore copepods (Calanus gracilis) and appendicularians were the main swimmers in the traps at $40 \mathrm{~m}$; a typically omnivorous copepod species (Metridia longa) prevailed in the intermediate traps, and in the deepest traps a carnivorous species (Paraeuchaeta glacialis) was most abundant after $M$. longa. Herbivorous conditions can be expected in the surface layer where primary production takes place, as well as an omnivorous or omnivorous/carnivorous regime at mesopelagic depths where deep-dwelling organisms and the vertical flux of organic matter are the main food sources. But together with our faecal pellet data we can now put forward that below the euphotic zone, there was omnivorous activity sustained largely by cyclopoid copepods, which were also present at the surface in a rather herbivorous environment, thus adding a heterotrophic component and suggesting epipelagic retention of faecal pellets as described in a review by Turner (2015) as a possible reason for the drastic reduction of cylindrical pellets in the deeper sediment traps. Such observations were made in the northern Barents Sea where zooplankton was responsible for up to $50 \%$ of retention of faecal pellet carbon within the euphotic layer (Wexels Riser et al., 2008), which lead to a significant flux attenuation around the depth of the pycnocline (Reigstad et al., 2008). Our observations add another component to these activities: coprophagous feeding at mesopelagic depths acting as a flux "hub" and increasing the contribution of faecal pellet carbon to the vertical POC flux at depth.

Even stronger evidence for the above scenario comes from the density level of the matter packed inside the faecal pellet membrane. Our data revealed a clear pattern for both morphotypes, with rather low-density pellets at the surface and high-density pellets at depth. Pellets within the $100 \%$ fullness category (see Sect. 3.4.1) were almost exclusively elliptical pellets, and they were only observed in the samples of the deepest traps. Feinberg et al. (1998) found in a feeding 
experiment with Acartia tonsa, that feeding on phytoplanktonic matter yielded pellets with low density, whereas feeding on heterotrophic matter resulted in a density increase of the pellets. Although we do not have experimental data from the copepod species present during our study, we can assume that the distribution pattern of the different categories of fullness reflected the trophic condition at each of the mooring locations. Within the euphotic zone, large calanoid copepods but also larvaceans are grazing upon the biomass issued from the primary production and consisting of photosynthetic flagellates and diatoms, as shown in our data from the microscopic investigation of the sinking material (cf. Fig. 8), and as reported by a pigment study in the same area (Coupel et al., 2015). Such food yields relatively low-density faecal pellets, which undergo bacterial degradation along their vertical sinking path, but also serve as a potential food source to the deeper-dwelling zooplankton community characterized by an omnivorous feeding behaviour. Although these pellets represent less than a third of the particle flux arriving in this zone, they are certainly part of the material described as a "fluffy and sticky gel-like matrix" by Forest et al. (2013) and composed among others, of ciliates and dinoflagellates (Fig. 8), which yield rather dense faecal pellets (Feinberg and Dam, 1998).

As a summary, the vertical particle flux measured within the shelf-basin area of the eastern Beaufort Sea during the late summer period of the 2009 Malina field campaign is at the lower end of fluxes registered in this area. However, similar or even lower fluxes have been reported from elsewhere in the Arctic Ocean (Cai et al., 2010; Chen et al., 2003). Compared to the long-term series data obtained from ArcticNet fixed moorings deployed in the vicinity, the fluxes from this study could be identified as background level flux, at least for the period 2008-2010 (Fig. 6). Although late August 2009 was a period of elevated fluxes for that year, the high spatial and also temporal variability of particle fluxes (cf. Forest et al., 2013) does not exclude short periods of minimal flux and indicates the event-driven nature of the particle flux in this region, that is, most of the time-averaged flux is probably taking place during short-lived events that are easily missed by short-term sampling. Extrapolation of short-term data should be done with much precaution, but situated within long-term series, such data sets can provide valuable information on processes that govern the fluxes under the given conditions. Integrated field studies such as the ArcticNet-Malina field campaign are an ideal platform to monitor these conditions. A rather complete set of complementary parameters measured on the sinking particles together with other data from the Malina study allowed us to analyse some processes involved in the export of particulate carbon from the surface to the deep ocean. In particular, we could highlight (1) the role of zooplankton, especially copepods, in the transformation of assimilated carbon by phytoplankton into particular organic carbon and (2) the transition of that carbon from the euphotic zone to the mesopelagic zone where it is re-processed by another zooplankton community. The former process, i.e. the role of zooplankton in shaping the export flux has been largely documented from the Barents Sea region (Wassmann et al., 2008 and references therein), but the latter process adds another piece to the puzzle that links the carbon flux to the trophic structure within the pelagic food web. Yet, we believe that these processes are also active during peak flux periods, since, as already mentioned by Forest et al. (2013), "the sinking POC can be viewed as what heterotrophic plankton were not able to assimilate". This shows the need not only for both short- and long-term surveys but also for an understanding of the mechanisms that lead to the transition between high and low fluxes (e.g. Andersen and Prieur, 2000), for which abiotic rather than biotic factors seem to be of primordial importance (Watanabe et al., 2014). Surely, in order to predict POC fluxes within a complex ecosystem such as the Arctic Ocean, all of physical, chemical and biological parameters are necessary to conceptualize and parameterize reliable models.

Acknowledgements. The International Atomic Energy Agency is grateful to the Government of the Principality of Monaco for the support provided to its Environment Laboratories. This study was conducted as part of the Malina Scientific Programme funded by ANR (Agence Nationale de la Recherche), INSU-CNRS (Institut National des Sciences de l'Univers - Centre National de la Recherche Scientifique) and CNES (Centre National d'Etudes Spatiales) from France, and ESA (European Space Agency). Additional support from ArcticNet (a Network of Centres of Excellence of Canada) was welcomed and appreciated. We thank the captain and crew of the Canadian Coast Guard research vessel Amundsen for their assistance at sea. We are particularly indebted to Nicolas Evensen (faecal pellets), Josephine Ras (pigments), Fernando Gomez (phytoplankton identification), Makoto Sampei (trap analyses) and Cyril Aubry (swimmers identification) for their laboratory contribution. Special thanks to Marc Picheral and Lars Stemmann for the processing of UVP data, and to Pascal Guillot for QA/QC of CTD profiles.

Edited by: P. Matrai

\section{References}

Amiel, D., Cochran, J. K., and Hirschberg, D. J.: ${ }^{234} \mathrm{Th} /{ }^{238} \mathrm{U}$ disequilibrium as an indicator of the seasonal export flux of particulate organic carbon in the North Water, Deep-Sea Res. Pt. II, 49, 5191-5209, 2002.

Andersen, V. and Prieur, L.: One-month study in the open NW Mediterranean Sea (DYNAPROC experiment, May 1995): overview of the hydrobiogeochemical structures and effects of wind events, Deep-Sea Res. Pt. I, 47, 397-422, 2000.

Archer, D., Winguth, A., Lea, D., and Mahowald, N.: What caused the glacial/interglacial atmospheric $p \mathrm{CO}_{2}$ cycles?, Rev. Geophys., 38, 159-189, 2000.

Baskaran, M., Swarzenski, P. W., and Porcelli, D.: Role of colloidal material in the removal of ${ }^{234} \mathrm{Th}$ in the Canada basin of the Arctic Ocean, Deep-Sea Res. Pt. I, 50, 1353-1373, 2003. 
Beaumont, K. L., Plummer, A. J., Hosie, G. W., and Ritz, D. A.: Production and fate of faecal pellets during summer in an East Antarctic fjord, Hydrobiologia, 453/454, 55-65, 2001.

Cai, P., van der Loeff, M. R., Stimac, I., Noethig, E. M., Lepore, K., and Moran, S. B.: Low export flux of particulate organic carbon in the central Arctic Ocean as revealed by ${ }^{234} \mathrm{Th}:{ }^{238} \mathrm{U}$ disequilibrium, J. Geophys. Res.-Oceans, 115, C10037, doi:10.1029/2009jc005595, 2010.

Carroll, M. L., Miquel, J. C., and Fowler, S. W.: Seasonal patterns and depth-specific trends of zooplankton fecal pellet fluxes in the Northwestern Mediterranean Sea, Deep-Sea Res. Pt. I, 45, 1303 $1318,1998$.

Chen, M., Huang, Y. P., Cai, P. G., and Guo, L. D.: Particulate organic carbon export fluxes in the Canada Basin and Bering Sea as derived from ${ }^{234} \mathrm{Th} /{ }^{238} \mathrm{U}$ disequilibria, Arctic, 56, 32-44, 2003.

Copin-Montégut, C., and Copin-Montégut, G.: Stoichiometry of carbon, nitrogen and phosphorus in marine particulate matter, Deep-Sea Res., 30, 31-46, 1983

Cottier, F. R., Tarling, G. A., Wold, A., and Falk-Petersen, S.: Unsynchronized and synchronized vertical migration of zooplankton in a high arctic fjord, Limnol. Oceanogr., 51, 2586-2599, 2006.

Coupel, P., Matsuoka, A., Ruiz-Pino, D., Gosselin, M., Marie, D., Tremblay, J.-É., and Babin, M.: Pigment signatures of phytoplankton communities in the Beaufort Sea, Biogeosciences, 12, 991-1006, doi:10.5194/bg-12-991-2015, 2015.

Daase, M., Eiane, K., Aksnes, D. L., and Vogedes, D.: Vertical distribution of Calanus spp. and Metridia longa at four Arctic locations, Mar. Biol., 4, 193-207, 2008.

Darnis, G. and Fortier, L.: Temperature, food and the seasonal vertical migration of key arctic copepods in the thermally stratified Amundsen Gulf (Beaufort Sea, Arctic Ocean), J. Plankton Res., 36, 1092-1108, 2014.

Deibel, D. and Turner, J. T., Zooplankton feeding ecology: contents of fecal pellets of the appendicularian Oikopleura vanhoeffeni, Mar. Ecol. Prog. Ser., 27, 67-78, 1985.

Emmerton, C. A., Lesack, L. F. W., and Warwick, V. F.: Mackenzie River nutrient delivery to the Arctic Ocean and effects of the Mackenzie Delta during open water conditions., Global Biogeochem. Cy., 22, GB1024, doi:10.1029/2006GB002856, 2008

Feinberg, L. R. and Dam, H. G.: Effects of diet on dimensions, density and sinking rates of fecal pellets of the copepod Acartia tonsa, Mar. Ecol.-Prog. Ser., 175, 87-96, 1998.

Forest, A., Sampei, M., Hattori, H., Makabe, R., Sasaki, H., Fukuchi, M., Wassmann, P., and Fortier, L.: Particulate organic carbon fluxes on the slope of the Mackenzie Shelf (Beaufort Sea): Physical and biological forcing of shelf-basin exchanges, J. Marine Syst., 68, 39-54, 2007.

Forest, A., Sampei, M., Makabe, R., Sasaki, H., Barber, D. G., Gratton, Y., Wassmann, P., and Fortier, L.: The annual cycle of particulate organic carbon export in Franklin Bay (Canadian Arctic): Environmental control and food web implications, J. Geophys. Res.-Oceans, 113, C03s05, doi:10.1029/2007jc004262, 2008.

Forest, A., Belanger, S., Sampei, M., Sasaki, H., Lalande, C., and Fortier, L.: Three-year assessment of particulate organic carbon fluxes in Amundsen Gulf (Beaufort Sea): Satellite observations and sediment trap measurements, Deep-Sea Res. Pt. I, 57, 125142,2010
Forest, A., Tremblay, J.-E., Gratton, Y., Martin, J., Gagnon, J., Darnis, G., Sampei, M., Fortier, L., Ardyna, M., Gosselin, M., Hattori, H., Dan, N., Maranger, R., Vaque, D., Marrase, C., PedrosAlio, C., Sallon, A., Michel, C., Kellogg, C., Deming, J., Shadwick, E., Thomas, H., Link, H., Archambault, P., and Piepenburg, D.: Biogenic carbon flows through the planktonic food web of the Amundsen Gulf (Arctic Ocean): A synthesis of field measurements and inverse modeling analyses, Prog. Oceanogr., 91, 410-436, 2011.

Forest, A., Stemmann, L., Picheral, M., Burdorf, L., Robert, D., Fortier, L., and Babin, M.: Size distribution of particles and zooplankton across the shelf-basin system in southeast Beaufort Sea: combined results from an Underwater Vision Profiler and vertical net tows, Biogeosciences, 9, 1301-1320, doi:10.5194/bg-91301-2012, 2012.

Forest, A., Babin, M., Stemmann, L., Picheral, M., Sampei, M., Fortier, L., Gratton, Y., Belanger, S., Devred, E., Sahlin, J., Doxaran, D., Joux, F., Ortega-Retuerta, E., Martin, J., Jeffrey, W. H., Gasser, B., and Miquel, J. C.: Ecosystem function and particle flux dynamics across the Mackenzie Shelf (Beaufort Sea, Arctic Ocean): an integrative analysis of spatial variability and biophysical forcings, Biogeosciences, 10, 2833-2866, doi:10.5194/bg10-2833-2013, 2013.

Gonzalez, H. E. and Smetacek, V.: The possible role of the cyclopoid copeopod Oithona in retarding vertical flux of zooplankton faecal material, Mar. Ecol. Prog. Ser., 113, 233-246, 1994.

Gonzalez, H. E., Gonzalez, S. R., and Brummer, G. J. A.: Short-term sedimentation pattern of zooplankton, feces and microplankton at a permanent station in the Bjornafjorden (Norway) during April May 1992, Mar. Ecol. Prog. Ser., 105, 31-45, 1994.

Honjo, S., Manganini, S. J., Krishfield, R. A., and Francois, R.: Particulate organic carbon fluxes to the ocean interior and factors controlling the biological pump: A synthesis of global sediment trap programs since 1983, Prog. Oceanogr., 76, 217-285, 2008.

Honjo, S., Krishfield, R. A., Eglinton, T. I., Manganini, S. J., Kemp, J. N., Doherty, K., Hwang, J., McKee, T. K., and Takizawa, T.: Biological pump processes in the cryopelagic and hemipelagic Arctic Ocean: Canada Basin and Chukchi Rise, Prog. Oceanogr., 85, 137-170, 2010.

Juul-Pedersen, T., Michel, C., and Gosselin, M.: Sinking export of particulate organic material from the euphotic zone in the eastern Beaufort Sea, Mar. Ecol.-Prog. Ser., 410, 55-70, 2010.

Kellogg, C. T. E., Carpenter, S. D., Renfro, A. A., Sallon, A., Michel, C., Cochran, J. K., and Deming, J. W.: Evidence for microbial attenuation of particle flux in the Amundsen Gulf and Beaufort Sea: elevated hydrolytic enzyme activity on sinking aggregates, Polar Biol., 34, 2007-2023, 2011.

Knauer, G. A. and Asper, V.: Sediment Trap Technology and Sampling, US GOFS Planning Report Number 10, US GOFS Planning Office, Woods Hole, Mass., 94 pp., 1989

Kosobokova, K. and Hirche, H. J.: Zooplankton distribution across the Lomonosov Ridge, Arctic Ocean: species inventory, biomass and vertical structure, Deep-Sea Res. Pt. I, 47, 2029-2060, 2000.

Kosobokova, K. N. and Hopcroft, R. R.: Diversity and vertical distribution of mesozooplankton in the Arctic's Canada Basin, Deep-Sea Res. Pt. II, 57, 96-110, 2010.

Lalande, C., Lepore, K., Cooper, L. W., Grebmeier, J. M., and Moran, S. B.: Export fluxes of particulate organic carbon in the 
Chukchi Sea: A comparative study using ${ }^{234} \mathrm{Th} /{ }^{238} \mathrm{U}$ disequilibria and drifting sediment traps, Mar. Chem., 103, 185-196, 2007.

Lalande, C., Forest, A., Barber, D. G., Gratton, Y., and Fortier, L.: Variability in the annual cycle of vertical particulate organic carbon export on Arctic shelves: Contrasting the Laptev Sea, Northern Baffin Bay and the Beaufort Sea, Cont. Shelf Res., 29, 21572165, 2009.

Lalande, C., Noethig, E.-M., Somavilla, R., Bauerfeind, E., Shevchenko, V., and Okolodkov, Y.: Variability in under-ice export fluxes of biogenic matter in the Arctic Ocean, Global Biogeochem. Cy., 28, 571-583, 2014.

Le Fouest, V., Zakardjian, B., Xie, H., Raimbault, P., Joux, F., and Babin, M.: Modeling plankton ecosystem functioning and nitrogen fluxes in the oligotrophic waters of the Beaufort Sea, Arctic Ocean: a focus on light-driven processes, Biogeosciences, 10, 4785-4800, doi:10.5194/bg-10-4785-2013, 2013.

Leu, E., Søreide, J. E., Hessen, D. O., Falk-Petersen, S., and Berge, J.: Consequences of changing sea-ice cover for primary and secondary producers in the European Arctic shelf seas, Prog. Oceanogr., 90, 18-32, 2011.

Lombard, F., Guidi, L., and Kiørboe, T.: Effect of Type and Concentration of Ballasting Particles on Sinking Rate of Marine Snow Produced by the Appendicularian Oikopleura dioica, PLoS ONE, 8, e75676, doi:10.1371/journal.pone.0075676, 2013

Lovejoy, C., Legendre, L., Martineau, M.-J., Bâcle, J., and von Quillfeldt, C. H.: Distribution of phytoplankton and other protists in the North Water, DeepSea Res. Pt. II, 49, 5027-5047, 2002.

Miquel, J.-C., Martín, J., Gasser, B., Rodriguez y Baena, A., Toubal, T., and Fowler, S. W.: Dynamics of particle flux and carbon export in the northwestern Mediterranean Sea: A two decade timeseries study at the DYFAMED site, Prog. Oceanogr., 91, 461481, 2011

Moran, S. B. and Smith, J. N.: ${ }^{234}$ Th as a tracer of scavenging and particle export in the Beaufort Sea, Cont. Shelf Res., 20, 153167,2000

O'Brien, M. C., Melling, H., Pedersen, T. F., and Macdonald, R. W.: The role of eddies and energetic ocean phenomena in the transport of sediment from shelf to basin in the Arctic, J. Geophys. Res.-Oceans, 116, C08001, doi:10.1029/2010jc006890, 2011.

Olli, K., Wassmann, P., Reigstad, M., Ratkova, T. N., Arashkevich, E., Pasternak, A., Matrai, P. A., Knulst, J., Tranvik, L., Klais, R., and Jacobsen, A.: The fate of production in the central Arctic Ocean - Top-down regulation by zooplankton expatriates?, Prog. Oceanogr., 72, 84-113, 2007.

Picheral, M., Guidi, L., Stemmann, L., Karl, D. M., Iddaoud, G., and Gorsky, G.: The Underwater Vision Profiler 5: An advanced instrument for high spatial resolution studies of particle size spectra and zooplankton, Limnol. Oceanogr. Methods, 8, 462-473, 2010.

Ras, J., Claustre, H., and Uitz, J.: Spatial variability of phytoplankton pigment distributions in the Subtropical South Pacific Ocean: comparison between in situ and predicted data, Biogeosciences, 5, 353-369, doi:10.5194/bg-5-353-2008, 2008.

Reigstad, M., Wexels Riser, Ch., and Svensen, C.: Fate of copepod faecal pellets and the role of Oithona spp., Mar. Ecol. Prog. Ser., 304, 265-270, 2005.

Reigstad, M., Wexels Riser, Ch., Wassmann, P., and Ratkova, T.: Vertical export of particulate organic carbon; Attenuation, com- position and loss rates in the northern Barents Sea, Deep-Sea Res. Pt. II, 55, 2308-2319, 2008.

Reigstad, M., Carroll, J., Slagstad, D., Ellingsen, I., and Wassmann, P.: Intra-regional comparison of productivity, carbon flux and ecosystem composition within the northern Barents Sea, Prog. Oceanogr., 90, 33-46, 2011.

Rutgers van der Loeff, M. M., Sarin, M. M., Baskaran, M., BenitezNelson, C. R., Buesseler, K. O., Charette, M. A., Dai, M., Gustafsson, O., Masque, P., Morris, P. J., Orlandini, K., Rodriguez y Baena, A. M., Savoye, N., Schmidt, S., Turnewitsch, R., Voge, I., and Waples, J. T.: A review of present techniques and methodological advances in analyzing ${ }^{234} \mathrm{Th}$ in aquatic systems, Mar. Chem., 100, 190-212, 2006.

Sallon, A., Michel, C., and Gosselin, M.: Summertime primary production and carbon export in the southeastern Beaufort Sea during the low ice year of 2008, Polar Biol., 34, 1989-2005, 2011.

Sampei, M., Sasaki, H., Hattori, H., Fukuchi, M., and Hargrave, B. T.: Fate of sinking particles, especially fecal pellets, within the epipelagic zone in the North Water (NOW) polynya of northern Baffin Bay, Mar. Ecol. Prog. Ser., 278, 17-25, 2004.

Sampei, M., Forest, A., Sasaki, H., Hattori, H., Makabe, R., Fukuchi, M., and Fortier, L.: Attenuation of the vertical flux of copepod fecal pellets under Arctic sea ice: evidence for an active detrital food web in winter, Polar Biol., 32, 225-232, 2009.

Schneider, B., Schlitzer, R., Fischer, G., and Nothig, E. M.: Depthdependent elemental compositions of particulate organic matter (POM) in the ocean, Global Biogeochem. Cy., 17, 1032, doi:10.1029/2002GB001871, 2003.

Siegenthaler, U., Stocker, T. F., Monnin, E., Lüthi, D., Schwander, J., Stauffer, B., Raynaud, D., Barnola, J.-M., Fischer, H., Masson-Delmotte, V., and Jouzel, J.: Stable Carbon CycleClimate Relationship During the Late Pleistocene, Science, 310, 1313-1317, 2005.

Svensen, C., Morata, N., and Reigstad, M.: Increased degradation of copepod faecal pellets by co-acing dinoflagellates and Centropages hamatus, Mar. Ecol. Prog. Ser., 516, 61-70, 2014.

Tamelander, T., Reigstad, M., Olli, K., Slagstad, D., and Wassmann, P.: New production regulates export stoichiometry in the ocean, PLoS ONE, 8, e54027, doi:10.1371/journal.pone.0054027, 2013.

Thor, P., Nielsen, T. G., Tiselius, P., Juul-Pedersen, T., Michel, C., Moller, E. F., Dahl, K., Selander, E., and Gooding, S.: Post-spring bloom community structure of pelagic copepods in the Disko Bay, Western Greenland, J. Plankton Res., 27, 341-356, 2005.

Tremblay, J.-É., Raimbault, P., Garcia, N., Lansard, B., Babin, M., and Gagnon, J.: Impact of river discharge, upwelling and vertical mixing on the nutrient loading and productivity of the Canadian Beaufort Shelf, Biogeosciences, 11, 4853-4868, doi:10.5194/bg11-4853-2014, 2014.

Turner, J. T.: Zooplankton fecal pellets, marine snow, phytodetritus and the ocean's biological pump, Prog. Oceanogr., 130, 205-248, 2015.

Utermöhl, H.: Neue Wege in der quantitativen Erfassung des Planktons (mit besonderer Berücksichtigung des Ultraplanktons), Verh. Internat. Verein. Limnol., 5, 567-596, 1931.

Walsh, J. E.: Climate of the Arctic marine environment, Ecol. Appl., 18, S3-S22, 2008.

Wassmann, P.: Arctic marine ecosystems in an era of rapid climate change, Prog. Oceanogr., 90, 1-17, 2011. 
Wassmann, P., Bauerfeind, E., Fortier, M., Fukuchi, M., Hargrave, B., Moran, B., Noji, T., Nöthig, E. M., Olli, K., Peinert, R., Sasaki, H., and Shevchenko, V.: Particulate organic carbon flux to the Arctic Ocean sea floor, in: The Organic Carbon Cycle in the Arctic Ocean, edited by: Stein, R., and MacDonald, R. W., Springer Berlin Heidelberg, 101-138, 2004.

Wassmann, P., Reigstad, M., Haug, T., Rudels, B., Carroll, M. L., Hop, H., Gabrielsen, G. W., Falk-Petersen, S., Denisenko, S. G., Arashkevich, E., Slagstad, D., and Pavlova, O.: Food webs and carbon flux in the Barents Sea, Prog. Oceanogr., 71, 232-287, 2006.

Wassmann, P., Carroll, J., and Bellerby, R. G. J.: Carbon flux and ecosystem feedback in the northern Barents Sea in an era of climate change: an introduction, Deep-Sea Res. Pt. II, 55, 2143 2153, 2008.

Watanabe, E., Onodera, J., Harada, N., Honda, M. C., Kimoto, K., Kikuchi, T., Nishino, S., Matsuno, K., Yamaguchi, A., Ishida, A., and Kishi, M. J.: Enhanced role of eddies in the Arctic marine biological pump, Nature Commun., 5, 3950, doi:10.1038/ncomms4950, 2014.

Wexels Riser, Ch., Wassmann, P., Olli, K., Pasternak, A., and Arashkevich, E.: Seasonal variation in production, retention, and export of zooplankton faecal pellets in the marginal ice zone and central Barents Sea, J. Mar. Sys., 38, 175-188, 2002.
Wexels Riser, Ch., Wassmann, P., Reigstad, M., and Seuthe, L.: Vertical flux regulation by zooplankton in the northern Barents Sea during Arctic spring, Deep-Sea Res. Pt. II, 55, 2320-2329, 2008.

Wiedmann, I., Reigstad, M., Sundfjord, A., and Basedow, S.: Potential drivers of sinking particle's size spectra and vertical flux of particulate organic carbon (POC): Turbulence, phytoplankton, and zooplankton, J. Geophys. Res.-Oceans, 119, 6900-6917, 2014.

Wilson, S. E., Steinberg. D. K., and Buesseler K. O.: Changes in fecal pellet characteristics with depth as indicators of zooplankton repackaging of particles in the mesopelagic zone of the subtropical and subarctic North Pacific Ocean, Deep-Sea Res. Pt. II, 55, 1636-1647, 2008.

Wilson, S. E., Ruhl, H. A., and Smith Jr., K. L.: Zooplankton fecal pellet flux in the abyssal northeast Pacific: A 15 year time-series study, Limnol. Oceanogr., 58, 881-892, 2013.

Wright, S. W. and Jeffrey, S. W.: Fucoxanthin pigment markers of marine phytoplankton analysed by HPLC and HPTLC, Mar. Ecol. Prog. Ser., 38, 259-266, 1987.

Yoon, W. D., Kim, S. K., and Han, K. N.: Morphology and sinking velocities of fecal pellets of copepod, molluscan, euphausiid, and salp taxa in the northeastern tropical Atlantic, Mar. Biol., 139, 923-928, 2001. 